\title{
Sizing of Energy Storage with Network Constraints Economic Dispatch of Fuel Cell Micro-Turbine and Renewable Energy Sources
}

\author{
Bharat Singh, Ashwani Kumar
}

\begin{abstract}
Micro-Grid is the appropriate solution to various problems in the power system. Different types of energy sources, likewise Fuel cell (FC), Micro-Turbine (MT) and renewable energy sources can be integrated with micro-grids (MG). The battery energy storage has played a crucial role to support the power mismatch of on-grid or off-grid MG. Therefore the optimal size of battery energy storage along with the optimal cost-based calculation has become an essential part for the micro-grid operator. The piecewise linear cost method is used for the cost based analysis. The main contribution of this paper is: (i) the optimal size of battery energy storage has been determined with a Fuel cell (FC) and Micro-Turbine (MT) based distribution generation (DG). (ii) The impact of battery storage with $D G$ and renewable energy sources (RES) has been considered. (iii) The total benefit and market benefit has been maximised. (iv) The unit-commitment cost of FC and MT with spinning reserve, piecewise linear cost function, ramp rate, minimum up and downtime constraints has been considered for the sizing of battery storage. (v) The network constrained has been found to obtain minimum daily energy loss for the optimal size of battery storage. (vi) The state of charge (SOC) of battery, the power output of DG's and RES, power loss, battery cost per day, operating cost of generation, etc. have been determined. The optimal sizing of battery energy storage determination is helpful for the both Microgrid operators as well as designers. The IEEE-33 bus test system with ZIP load has been carried out for analysis and result validation. The general algebraic modeling system (GAMS) is used to solve the deterministic optimisation problem.
\end{abstract}

Keywords: Battery Energy Storage Device (BES), Energy Loss, Market Benefit, Unit Commitment, Piecewise linear function, Renewable Energy Sources.

\section{INTRODUCTION}

In recent years, renewable energy has been intermittent with micro-grid (MG) in a large scale. The intermittency of renewable and distributed generation (DG) has become an essential need for storage in MG. The optimum sizing of storage devices has become an essential task for MG operators. Although the size of energy storage is varying in nature from the type to type of DG's. The sizing of battery storage must be considered with market benefit in MG with various energy sources along with the network constraints.

Revised Manuscript Received on June 15, 2020. Correspondence Author*

Bharat Singh*, Electrical Engineering department, NIT Kurukshetra, Haryana, India. Email: bharat_6180045@nitkkr.ac.in

Dr. Ashwani Kumar, Senior IEEE member, Electrical Engineering department, NIT Kurukshetra, Haryana, India.Email: ashwa_ks@yahoo.co.in

(C) The Authors. Published by Blue Eyes Intelligence Engineering and Sciences Publication (BEIESP). This is an open access article under the CC BY-NC-ND license (http://creativecommons.org/licenses/by-nc-nd/4.0/)
The optimal size of BES has studied not only the total benefit of energy sales but also to reduce the energy loss of the distribution network.

The power loss saving is another issue for MG operators. The energy-saving capacity with renewable PV power generation using the rooftop installation of $\mathrm{PV}$ has represented in [1]. A potential game model has described in [2] for battery energy storage scheduling with renewable sources. The loss saving has been discussed with the installation of a photovoltaic (PV) system in the network [3]. In recent years, the power loss minimisation and energy-saving problem based on random search methods have been published. The metaheuristic Ant Lion Optimization (ALO) algorithm had used to determine the optimal DG size for loss minimisation [4]. The sizing of battery energy storage based literature has considered in MG for cost based objectives. Chen, S. X et al. [5], has determined the size of battery storage with costbenefit based unit commitment problem but the minimum up and downtime constraints did not consider. The FC and MT have been taken into account for the unit commitment (UC) problem without network constraints also.

Bahmani-Firouzi et al. [6] the bat algorithm has been implemented for determining the size of battery storage. The piecewise linear cost function, minimum up and downtime constraints did not consider in[6]. To minimises the power losses and expected operational cost of the microgrid with the stochastic problem had been represented in [7]. The nonlinear constraints multi-objective has been solved using Adaptive Modified Particle Swarm Optimization algorithm (AMPSO) is presented for MG dispatch with FC, MT and battery storage as a back-up [8]. The battery model was solved using RungeKutta method for standalone hybrid PV-battery system [9]. The conditional depreciation balancing strategy had used for hybrid energy storage and virtual battery model and compared with the state of charge method also [10]. The automatic segmentation method and the segmentation method are proposed to obtain the capacity of the battery energy storage system [11]. The formal mathematical model combined with power network topology has been represented for FC and MT integrated MG system [12]. V.V.S.N. Murty et al. [13] has represented Fuzzy logic based energy storage system scheduling for optimal energy dispatch strategy and energy saving.

Published By:

Blue Eyes Intelligence Engineering \& Sciences Publication

$881^{\text {C) Conviriaht }}$ All riahts reserved

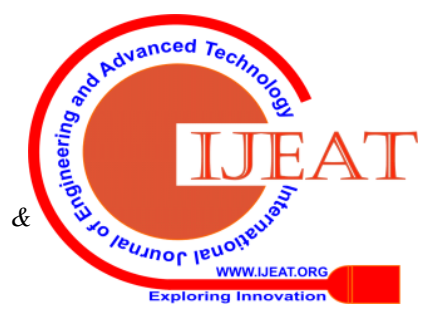


The unit commitment was not considered in [13]. The probabilistic approach has been represented in [14] for the sizing of battery storage with Wind Turbine power fluctuations. The dispatching methodology with the cost-based rule has represented using Monte Carlo simulation (MCS) for micro-grids [15]. The solar radiation model using MCS as described in [16], but the battery storage has not considered.

G.Ma et al.[17] has considered the simplified unit commitment (UC) of generating units along with a one-hour time scale for energy storage with renewable Wind turbines and solar. The priority-based UC problem has been solved with demand-side biding of controllable loads in paper [18]. The UC of the diesel plant has been considered using the mixed-integer formulation for the rating of the energy storage system along with isolated Wind Turbine-diesel. The marketable reduction in cost has been concluded utilising the combination of the energy storage system (ESS) and diesel generator in paper [19]. The total generation cost for the unit commitment problem using the gravitational search algorithm gives the batter results, computation time and precision for the energy storage system in MG application in [20]. A piecewise linear approximation and integer algebra have been implemented for linear expression of nonlinearities with the renewable energy sources in paper [21]. The piecewise linear approximation constraints have also been used for computation of power loss in low voltage grid-connected battery storage system [22]. The battery storage has been considered with residential PV system in [23]. The energy saving issue has also been considered with influence of storage and PV system in literature [24]-[25].

In the above literature from [1] to [26] the various algorithm and techniques have been used for energy loss minimisation using renewable energy sources along with the BES. The multiple algorithm used for determining the size of BES with the installation of FC, MT, Wind Turbine (WT) and PV has been discussed in the literature [6] to [12]. The UC problem with spinning reserve has been considered for the sizing of BES in [17] to [22].

In this paperwork, the size of battery storage has been determined by considering the Fuel cell (FC), and MicroTurbine (MT) based DG's along with Wind Turbine and solarbased renewable energy sources. The sizing of battery energy storage has been obtained, considering the impact of renewable-based energy sources also.

\section{PROBLEM FORMULATION AND MATHEMATICAL MODEL}

In this paperwork, the optimal size of battery energy storage has been obtained. The size of BES has been determine considering the multi-objective function. The multi-objective function have been considered as follows;

(i) To maximise the total benefit, including the cost of power sale/ punches from the grid.

(ii) To minimise the daily energy loss profile.

In this paper, the objective function has consisted of the outer layer and inner layer optimisation problem. a. In the outer layer optimisation problem, an iterative algorithm has been solved. The BES has been obtained at each iteration. The total benefit, market benefit, cost of UC and daily energy loss curve have been obtained at each size of BES. Based on the result of the outer layer optimisation problem, the best size of BES has been obtained. The battery size has been obtained at that iteration having the minimum daily energy loss value and maximum market benefit.

b. In the inner layer optimisation problem, the obtained size of BES from outer layer optimisation has been analysed as follows;

1) The UC problem, spinning reserve, the total hourly spinning reserve has been solved.

2) The piecewise linear cost function has been solved for determining the fuel cost of FC and MT units.

3) The start-up and shut-down cost of generators have been determined with up-time and down-time constraints.

4) The total power output of FC, MT, PV and WT have been determined.

5) The state of charge SOC, charging and discharging power of BES has been obtained.

The outer layer optimisation has been solved using MATLAB simulation, whereas the inner layer optimisation problem has been solved using MINLP technique in GAMS software.

The algorithm has been solved for various case study. The unit commitment with spinning reserve has been considered for dispatch-able sources; likewise, Fuel cell and microturbine (MT). The renewable-based Wind Turbine and PV energy sources have been considered in this scenario.

In this paperwork, the IEEE 33 bus test system has been carried out. The time-varying ZIP load has been taken into account for the analysis. The impact of battery energy storage with and without renewable energy sources has also been analysed. The unit commitment problem has been formulated, including piecewise cost segment, ramp rate, minimum uptime and downtime constraints. The problem is solved by MINLP solver in GAMS. The data interpretation has been done with the interfacing of MATLAB and GAMS software.

\section{A. Mathematical Modelling}

In this section the mathematical modelling of Solar, Wind Turbine, Fuel Cell, Micro-Turbine and battery storage has been represented as follows;

\section{1) PV Panel modeling}

The PV generator is the renewable source which provides the DC at $48 \mathrm{~V}$. The Monte Carlo Simulation (MCS) has been taken for the exact modelling of solar power output. In this scenario, 1000 numbers of the sample have been chosen for simulation [23].

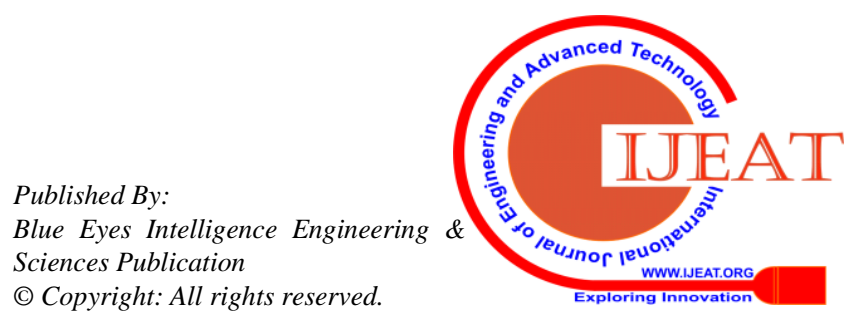


The solar PV model is;

$P_{\text {solar }}\left(I_{\beta}\right)=N_{P V} \cdot P_{\text {rated }}^{P V} \frac{G}{G 0} \cdot\left\{1-T_{c}\left(T_{A}-25\right)\right\} \cdot \eta_{\text {inv }} \eta_{r l}$

where, $P_{\text {solar }}$ is the output power, $P_{\text {rated }}^{P V}$ rated power of PV, and $N_{P V}$ is the total number of solar panel [16]. $G$ and $G 0$ are solar irradiation and slandered solar irradiation in $\left(\frac{w a t t}{m^{2}}\right)$.The Fig. 1 shows solar PV output for 24 hours. $T_{A}$ is the ambient temperature and $\mathrm{Tc}$ is the temperature coefficient of the maximum power of PV. $\square_{i n v}$ and $\square_{r l}$ represent the efficiency of the inverter and the relative efficiency of the PV modules respectively.

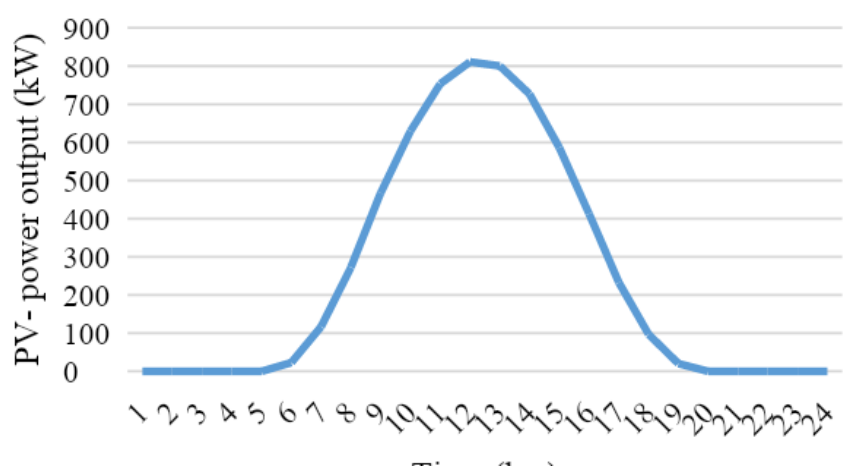

Fig. 1 Solar power output curve for 24 hrs

\section{2) Wind Turbine Power Model}

In this paper, the quadratic model of Wind Turbine has been taken. The wind turbine output is shown in Fig 2. The Wind Turbine model is as:

$$
\begin{aligned}
& P_{\text {wind }}=\left\{P_{\text {rated }}\left(\frac{\left(v-v_{\text {in }}\right)^{2}}{\left(v_{r}-v_{\text {in }}\right)^{2}}\right) ; v_{\text {in }} \leq v \leq\right. \\
& v_{r} P_{\text {rated }} ; \quad v_{r} \leq v \leq v_{\text {out }} 0 \\
& v_{\text {out }} \text { and } v<v_{\text {cut }}
\end{aligned}
$$

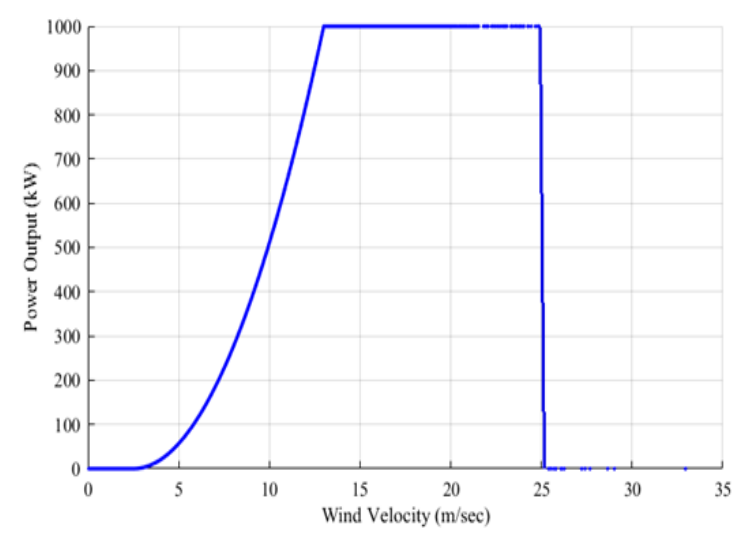

Fig. 2 Wind Turbine power output curve

where, $P_{\text {rated }}$ is the rated Wind Turbine power, $P_{\text {wind }}$ is the Wind-Turbine power output $v_{\text {in }}$ is cut in the velocity of Wind Turbine, $v_{\text {out }}$ is cut out Wind Turbine velocity.

\section{3) Battery Storage Model}

The battery storage works as back-up storage. The discharging and charging power limits of battery are the control parameters. The maximum value depends on the nominal capacity, while the minimum value depends on its Depth of Discharge (DOD).

$$
\begin{aligned}
& S O C_{\min }=N_{\text {bat }} \text { Batt }_{\text {size }}\left(1-D O D_{\text {max _bat }}\right) \\
& \text { SOC }_{\text {max }}=N_{\text {bat }} \text { Batt }_{\text {size }} \\
& \operatorname{SOC}(i, k+\Delta k)=\operatorname{SOC}(i, k) \cdot(1-\delta)+\left(P_{c h}{ }_{i}^{k} \cdot \eta_{c h}-\right. \\
& \text { Pdisik.1ndis. } \Delta k
\end{aligned}
$$

Eq.(3) and (4) are represent the minimum and maximum value of BES, whereas Eq.(5) is represent the state of charge (SOC) calculation for battery storage device.

where, $k$ is time in hrs $1,2, \ldots .24$ and $\Delta k$ is the time step. $D O D_{\text {max _bat }}$ is the maximum depth of discharge, $B a t t_{\text {size }}$ is the nominal capacity $(\mathrm{kWh}), N_{b a t}$ total number of battery, $S O C$ is a state of charge, $P_{c h}$ charging power, $P_{d i s}$ is discharging power, $\square_{c h}$ and $\square_{\text {dis }}$ are the charging and discharging efficiency of the battery.

The discharging schedule depends on the SOC of battery also. Once the peak energy-saving is stabilized the discharging of battery is as follows;

$$
\begin{aligned}
& E_{\text {dis } i, k}^{\min }=\int_{k}^{T}\left(P d_{\text {Load }, i}^{k}-\left(\operatorname{Pgrid}_{i}^{k}\right)-\max \left(P_{\text {gen }_{i}}^{k}\right)\right) \Delta t \\
& \text { if } P d_{\text {Load }, i}^{k} \geq\left(\operatorname{Pgrid}_{i}^{k}\right)
\end{aligned}
$$

where, $P_{\text {gen }}^{k}{ }_{i}$ is the generator output at each $\mathrm{i}^{\text {th }}$ bus for $\mathrm{k}^{\text {th }}$ time, $\operatorname{Pgrid}_{i}^{k}$ is grid power, $P d_{\text {Load,i }}^{k}$ load demand. $\forall i=$ $1,2 \ldots n b$ and $. \forall k=1,2 \ldots T, T$ is total time .i.e $24 \mathrm{hrs}$.

The charging schedule of battery energy storage has scheduled based on peak energy saving. The renewable-based DGs has stabilised to supply the load as well as to supply the battery storage. Once the peak energy is scheduled based on the lower market bid as well as the availability of renewable energy the formulation of charging of battery storage has determined as follows;

$$
\begin{aligned}
& \quad E_{c h_{i, k}}^{\min }=\int_{k}^{T}\left(\left(\operatorname{Pgrid}_{i}^{k}\right)+\left(P_{g_{e n}}{ }_{i}\right)-P d_{\text {Load }, i}^{k}\right) \Delta t \\
& \text { if } P d_{\text {Load }, i}^{k} \leq\left(\operatorname{Pgrid}_{i}^{k}\right)
\end{aligned}
$$

where, $E_{c h_{i, k}}^{\min }$ and $E_{d i s} \min _{i, k}$ are minimum charging and discharging the energy of battery energy storage.

\section{4) Fuel Cell (FC) Model}

The fuel cells are considered as a clean energy source because FCs do not need conventional fuel. FC has a higher efficiency than a diesel engine and simple to maintain also. FC has needed the continuous source of fuel and oxygen; therefore, FCs are differed with the battery as per longer operating time. The cost of a fuel cell $\left(\right.$ Cost $\left._{F C}\right)$ depends on the FC's efficiency $\left(\square_{F C}\right)$ and power output $\left(P_{g e n_{i}}{ }_{i}\right)$ of a fuel cell.

$$
\operatorname{Cost}_{F C}=\left(\frac{P_{g e n_{i}^{F C}}}{\eta_{F C}}\right) C_{\text {su }} u_{f u e l_{-} F C}
$$

where, $C s u_{f u e l_{-} F C}$ is price to supply of fuel $(\$ / \mathrm{kWh})$.

Blue Eyes Intelligence Engineering \& Sciences Publication

$883^{(C)}$ Convriaht· All riahts reserver

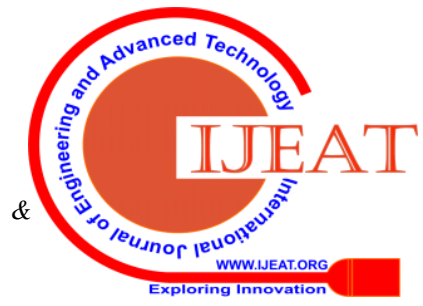




\section{5) Micro-Turbine}

MT has more benefits as compared to conventional heat engine in terms of the low maintenance cost, small compact size, more substantial reliability, low emission and flexible operation of the fuel. The cost of MT $\left(\operatorname{Cost}_{M T}\right)$ depends on the MT's efficiency ( $\left.\square_{M T}\right)$ and active power output $\left(P_{g e n}{ }_{i}{ }^{M T}\right)$ of MT.

\section{6) Piecewise linear cost model of FC and MT generation}

The piecewise linear cost function has been carried out for Fuel cell (FC) and Micro-Turbine (MT) generation. The number of segments is used for piecewise linear cost model[27]. The cost segments have been made for power segments $\left(\Delta P_{i, k}^{s g}\right)$.

$$
\begin{aligned}
& 0 \leq P_{i, k}^{s g} \leq \Delta P_{i, k}^{s g} \cdot U_{i, k}^{g e n} ; \forall s g \in n s g \\
& \Delta P_{i, k}^{s g}=\frac{\left(P_{g e n} \max _{i, k}-P_{g e n} \min _{i, k}\right)}{n s g} \\
& P_{i, k, i n i}^{s g}=(s g-1) \Delta P_{i, k}^{s g}+P_{g e n} \min _{i, k} \\
& P_{i, k, \text { final }}^{s g}=\Delta P_{i, k}^{s g}+P_{i, k, \text { ini }}^{s g} \\
& P_{g e n_{i}}{ }_{i}=P_{g e n_{i, k}}^{\min } \cdot U_{i, k}^{g e n}+\sum_{s g}^{n s g} \quad\left\{\Delta P_{i, k}^{s g}\right\} \\
& \text { Cost }_{g e n}^{s g}{ }_{i, k, i n i}=\left\{a_{i}\left(P_{i, k, i n i}^{s g}\right)^{2}+b_{i} P_{i, k, i n i}^{s g}+c_{i}\right\} \\
& \text { Cost }_{\text {gen }}^{s g} \underset{i, k, \text { final }}{s g}=\left\{a_{i}\left(P_{i, k, f \text { inal }}^{s g}\right)^{2}+b_{i} P_{i, k, \text { final }}^{s g}+c_{i}\right\}
\end{aligned}
$$

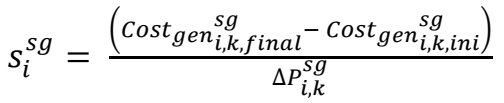

$$
\begin{aligned}
& \text { Cost } \text { fuel }_{\text {gen }}=U_{i, k}^{\text {gen }}\left\{a_{i}\left(P_{\text {gen }}{ }_{i}^{k}\right)^{2}+b_{i} P_{\text {gen }}{ }_{i}^{k}+c_{i}\right\}+ \\
& \sum_{s g}^{n s g} \quad\left\{s_{i}^{s g} \Delta P_{i, k}^{s g}\right\} \\
& \forall \text { gen } \in(F C, M T)
\end{aligned}
$$

where, nsg is total number of segments, $U_{i, k}^{g e n}$ is the on/off status of FC and MT units at time $\mathrm{k}, P_{g e n_{i, k}}^{\max }$ and $P_{g e n_{i, k}} \min$ maximum and minimum power limits of FC and MT respectively, Cost $_{g e n}{ }_{i, k, \text { ini }} g$ and $\operatorname{Cost}_{\text {gen }}{ }_{i, k, \text { final }}$ are initial and final cost segment of FC and MT generation. Cost $_{\text {fuel }}^{\text {gen }}$ is the fuel cost of FC and MT. $a_{i}, b_{i}$ and $c_{i}$ are the cost coefficients of FC and MT respectively.

\section{7) Load Model}

In this paper, the time-varying ZIP load model is represented. The constant impedance, constant current and constant power load model for residential, commercial and industrial loads has been carried out for the analysis.

The expressions for zip load model is represented as follows;

$$
\begin{aligned}
& P_{i, k}^{Z I P}=P d_{i}\left[Z_{p}\left(\frac{V_{i}^{k}}{V_{\text {min }}^{k}}\right)^{2}+I_{p}\left(\frac{V_{i}^{k}}{V_{\text {min }}^{k}}\right)+P_{p}\right] \\
& Q_{i, k}^{Z I P}=Q d_{i}\left[Z_{q}\left(\frac{V_{i}^{k}}{V_{\text {min }}^{k}}\right)^{2}+I_{q}\left(\frac{V_{i}^{k}}{V_{\text {min }}^{k}}\right)+P_{q}\right]
\end{aligned}
$$

$\forall\left\{Z_{i}+I_{i}+P_{i}=1\right\}$, where, $Z_{i}, I_{i}$ and $P_{i}$ are the constant impedance, constant current and constant power load parameter for different type of costumer [28]. $P d_{i}$ and $Q d_{i}$ are the load demand at each bus i. The active and reactive part of ZIP load is shown in Fig 3.
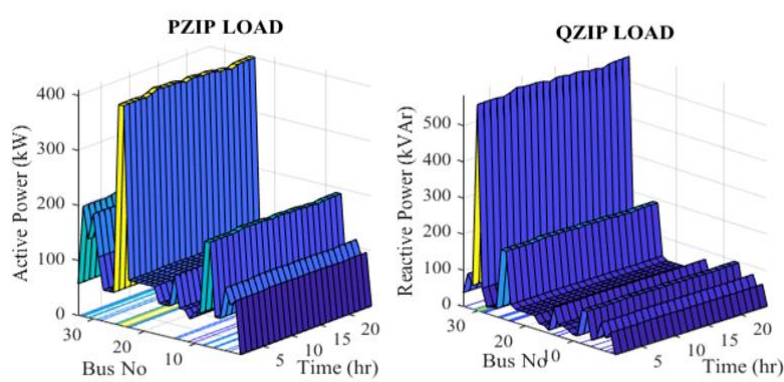

Fig. 3 ZIP Load profile [35]

\section{8) Micro-Grid}

The network consistence of IEEE-33 bus test system.

In Fig. 4 the FC at $21^{\text {st }}$ bus, MT-1 and MT-2 at bus $5^{\text {th }}$ and $11^{\text {th }}$, WT at $15^{\text {th }}$ bus and PV at $30^{\text {th }}$ bus have been installed for optimal size of battery storage at $19^{\text {th }}$ bus.

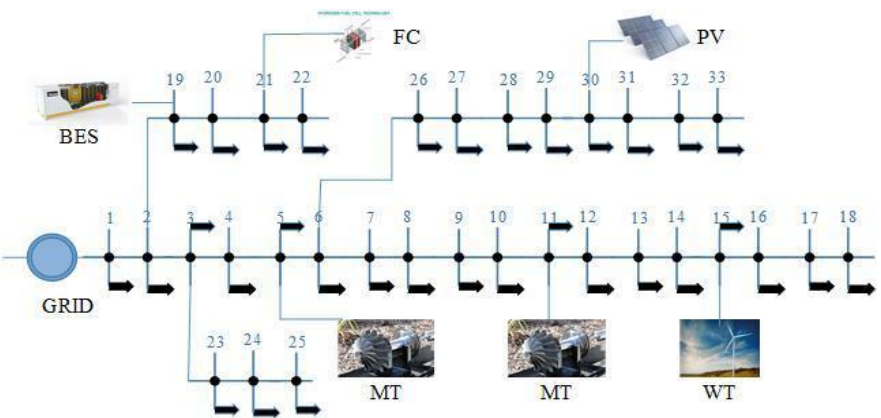

Fig. 4 MG network with Energy Resources

\section{B. Problem formulation}

The following objective function has formulated as:

\section{1) Objective function formulation}

The multi-objective function is to maximising the total benefit of grid-connected micro-grid and minimising the daily energy loss profile of the network. The multi-objective function $f_{1}$ and $f_{2}$ formulated as follows;

$\max \left\{f_{1}\right\}=$ Market $_{\text {Benefit }}-$ Batt $_{C P D}$

$\min \left\{f_{2}\right\}=\sum_{k}^{T} \quad \sum_{i}^{n b} \quad G_{i j}^{k}\left\{\left(V_{i}^{k}\right)^{2}+\left(V_{i}^{k}\right)^{2}-2 V_{i}^{k} V_{j}^{k}\right.$

$\square \square \square \cos \square i k-\delta j k$

Market $_{\text {Benefit }}=\sum_{k}^{T} \quad\left\{\right.$ Price $_{\text {Market }} \cdot \sum_{i}^{n b} \quad P_{\text {gen }}{ }_{i}-$ UCCdisp

$U C C_{\text {disp }}=$

$\sum_{k}^{T} \quad \sum_{i}^{n b} \quad\left\{r R n_{i, k}+\operatorname{Cost}_{i, k}^{\text {gen }}+\left(U_{i, k}^{\text {wind }}\right.\right.$ voll $\left.^{\text {wind }}\right)$.

Pi,kwind+Ui,kPVvollPV.Pi,kPV

Published By:

Blue Eyes Intelligence Engineering \& Sciences Publication

884 (c) Copyright: All rights reserved. 
Cost $_{i, k}^{g e n}=S T C_{i, k}^{g e n}+S D C_{i, k}^{g e n}+U_{i, k}^{g e n}\left\{a_{i}\left(P_{g e n}{ }_{i}^{k}\right)^{2}+\right.$ biPgenik +ci +sgnsgsisg $\Delta$ Pi,ksg

Batt $_{C P D}=\left\{\left(\frac{r t .(1+r t)^{y r}}{(1+r t)^{y r}-1}\right) \cdot B a t t_{f c}+B a t t_{M C}\right\} \frac{\text { Batt }_{\text {Size }}}{365}$

where, $U C C_{\text {disp }}$ unit commitment cost for generating unit, $R n_{i, k}$ spinning reserve for ith unit at kth time, $\operatorname{Cost}_{i, k}^{g e n}$ is operating cost of generation unit .i.e. FC and MT. $P_{i, k}^{\text {wind }}$ is power output of $\mathrm{i}^{\text {th }}$ Wind Turbine unit at $\mathrm{k}^{\text {th }}$ time. voll $l^{\text {wind }}$ and $\operatorname{voll}^{P V}$ are the value of Wind Turbine and PV respectively. $P_{i, k}^{P V}$ is power output of $\mathrm{i}^{\text {th }} \mathrm{PV}$ unit at $\mathrm{k}^{\text {th }}$ time. $U_{i, k}^{\text {wind }}$ and $U_{i, k}^{P V}$ are the on/off status of Wind Turbine and solar $\mathrm{PV}$ respectively. Batt $_{C P D}$ is the battery cost per day, $\mathrm{rt}$ is interest rate, yr is number of year to use battery, Batt $f_{c}$ and Batt $_{M C}$ are the fixed and maintenance cost of battery storage.

Constraints Equations are as follows;

(i) Power balance constraints;

$$
P_{i}^{k}=\left(P g_{i}^{k}+P g r i d_{i}^{k}-P d_{Z I P, i}^{k}\right)
$$

$=V_{i}^{k} \sum_{j=1}^{n} V_{j}^{k}\left(G_{i j}^{k} \cos \cos \left(\delta_{i}^{k}-\delta_{j}^{k}\right)+B_{i j}^{k}\right.$

sinsin $\delta i k-\delta j k \quad(27)$

$$
Q_{i}^{k}=\left(Q g_{i}^{k}+Q \operatorname{grid}_{i}^{k}-Q d_{Z I P, i}^{k}\right)
$$

$=V_{i}^{k} \sum_{j=1}^{n} \quad V_{j}^{k}\left(G_{i j}^{k} \sin \sin \left(\delta_{i}^{k}-\delta_{j}^{k}\right)-B_{i j}^{k}\right.$

$\operatorname{coscos} \delta i k-\delta j k$ (28) $\quad \forall i \in S B \& k \in S T$

where $\forall i=1,2 \ldots . n b, \forall j=1,2 \ldots . n l, n b$ is a number of buses and $n l$ is the total number of line. $S_{B}$ is the set of buses, and $S_{T}$ is the set of Time k. $P d_{i}^{k}$ and $Q d_{i}^{k}$ are the active and reactive power demand for $\mathrm{i}^{\text {th }}$ bus at $\mathrm{k}^{\text {th }}$ time period.

(ii). Power generation constraints:

$P g_{i}^{k}=P_{g e n, i}^{k}+N_{\text {wind }}(i) \cdot P_{\text {wind }_{i}}^{k}+N_{P V}(i) \cdot P_{P V_{i}}^{k}+$ $N_{\text {batt }}(i) \cdot\left(P_{c h}{ }_{i}^{k}-P_{\text {dis }}{ }_{i}^{k}\right)$

$Q g_{i}^{k}=Q_{\text {gen }_{i}}^{k}+N_{\text {wind }}(i) \cdot Q_{\text {wind }_{i}}^{k}$

where, $P_{g e n}{ }_{i}^{k}$ and $Q_{g e n}{ }_{i}^{k}$ are the active and reactive power supplied by diesel generator for $\mathrm{i}^{\text {th }}$ bus at $\mathrm{k}^{\text {th }}$ time period.

(iii). Ramp rate constraints;

The ramp rate constraints for generation of fuel cell and micro turbine has been represented as;

$$
\begin{aligned}
& P_{\text {gen }_{i}}{ }^{k} \leq P_{g e n_{i, k}}^{\max }\left[U_{i, k}^{g e n}-X_{i, k+1}^{g e n}\right]+S D_{i, k}^{g e n} \cdot X_{i, k+1}^{g e n} \\
& P_{\text {gen }}{ }_{i} \leq P_{\text {gen }_{i}}{ }^{k-1}+R U_{i, k}^{g e n} \cdot U_{i, k-1}^{g e n}+S U_{i, k}^{g e n} Y_{i, k+1}^{g e n} \\
& P_{\text {gen }}{ }_{i}^{k} \geq P_{\text {gen }}{ }_{i, k}^{\text {min }} U_{i, k}^{g e n} \\
& P_{g e n_{i}}{ }^{k} \geq P_{g e n_{i}}{ }^{k-1}-R D_{i, k}^{g e n} \cdot U_{i, k}^{g e n}-S D_{i, k}^{g e n} \cdot X_{i, k}^{g e n}
\end{aligned}
$$

(iv). Start up/Down cost constraints;

$$
\begin{aligned}
& Y_{i, k}^{g e n}-X_{i, k}^{g e n}=U_{i, k}^{g e n}-U_{i, k-1}^{g e n} \\
& Y_{i, k}^{g e n}+X_{i, k}^{g e n} \leq 1 \\
& S T C_{i, k}^{g e n}=\operatorname{Cost}_{i, k}^{S T} Y_{i, k}^{g e n} \\
& S D C_{i, k}^{g e n}=\operatorname{Cost}_{i, k}^{S D} X_{i, k}^{g e n}
\end{aligned}
$$

(v). Start up/Down Time constraints

Minimum up time $\left(U T_{i}\right)$ constraints is modelled as;

Retrieval Number: E9871069520/2020@BEIESP

DOI: 10.35940/ijeat.E9871.069520

Journal Website: www.ijeat.org

$$
\begin{aligned}
& \sum_{k}^{T-U T_{i}+1} \quad\left(1-U_{i, k}^{g e n}\right)=0 \\
& \sum_{k=s g}^{s g-U T_{i}+1} \quad\left(U_{i, k}^{g e n}\right) \geq U T_{i} \cdot Y_{i, k}^{g e n} \\
& \sum_{k=s g}^{T} \quad\left(1-Y_{i, k}^{g e n}\right) \geq 0 \\
& \forall s g=T-U T_{i}+2 \ldots . T
\end{aligned}
$$

Minimum down time $\left(D T_{i}\right)$ constraints is modelled as;

$\sum_{k}^{T-U T_{i}+1} \quad\left(U_{i, k}^{g e n}\right)=0$

$\sum_{k=s g}^{s g-U T_{i}+1} \quad\left(1-U_{i, k}^{g e n}\right) \geq D T_{i} \cdot X_{i, k}^{g e n}$

$\sum_{k=s g}^{T} \quad\left(1-U_{i, k}^{g e n}-X_{i, k}^{g e n}\right) \geq 0$

$\forall s g=T-D T_{i}+2 \ldots . . T$

where, $U_{i, k}^{g e n}, X_{i, k}^{g e n}, Y_{i, k}^{g e n}, \in(1,0)$, is the binary variables. $S D_{i, k}^{g e n}$ and $S U_{i, k}^{g e n}$ are shut down and start-up cost constants of FC and MT. $\operatorname{Cost}_{i, k}^{S D}$ and $\operatorname{Cost}_{i, k}^{S T}$ are the cost coefficients of shut down and start up for FC and MT respectively. $S T C_{i, k}^{g e n}$ and $S D C_{i, k}^{g e n}$ are start-up and shut down cost for generating unit.

(vii). Power Loss equation

$$
\begin{gathered}
\left|P_{i j}^{k}\right|=\mid \sum_{k}^{T} \sum_{i}^{n b} G_{i j}^{k}\left\{\left(V_{i}^{k}\right)^{2}+\left(V_{i}^{k}\right)^{2}-2 V_{i}^{k} V_{j}^{k}\right. \\
\left.\cos \cos \left(\delta_{i}^{k}-\delta_{j}^{k}\right)\right\} \mid
\end{gathered}
$$

$\leq P l_{\max }^{k}$

where, $P l_{\text {max }}^{k}$ is the maximum apperent power flow through the line at kth hrs. $l \in S_{L}$ is the set of line.

Inequality constraints:

(viii). Constraints for Transmission line

$$
\begin{aligned}
& P_{\text {smin }_{j}}{ }^{k} \leq P_{f s} \leq P_{f_{\text {smax }}}{ }_{j}, i \in S_{f s} \\
& Q_{f \operatorname{smin}_{i}}^{k} \leq Q_{f s_{j}} \leq Q_{\text {ssmax }_{j}}^{k}, i \in S_{f r} \\
& P_{\text {frmin }_{j}}^{k} \leq P_{f r} \leq P_{\text {frmax }_{j}}^{k}, \quad i \in S_{f r} \\
& Q_{\text {frmin }_{i}}{ }^{k} \leq Q_{f_{r}} \leq Q_{\text {frmax }_{j}}^{k}, i \in S_{f r}
\end{aligned}
$$

(ix). Capacity Limits of the generation system

$$
\begin{aligned}
& P_{G i}^{\min } \leq P g_{i} \leq P_{g i}^{\max }, i \in S_{G} \\
& Q_{g i}^{\min } \leq Q g_{i} \leq Q_{g i}^{\max }, i \in S_{G} \\
& \quad \text { (x). Voltage and angle limits } \\
& V_{i, k}^{\min } \leq V_{i}^{k} \leq V_{i, k}^{\max }, i \in S_{B} \\
& \square_{\text {min }_{i}}{ }^{k} \leq \delta_{i}^{k} \leq \delta_{\text {max }_{i}}^{k}, \forall i=1,2 \ldots . n b
\end{aligned}
$$

(xi). Power factor limits

$$
p f_{i}^{l o} \leq p f_{i} \leq p f_{i}^{u p}, i \in S_{B}
$$

Published By:

Blue Eyes Intelligence Engineering \& Sciences Publication

$885^{\text {C) Convriaht }}$ All riahts reserved 
(xii) Energy storage constraints;

$$
\begin{aligned}
& \operatorname{SOC}_{i}^{\text {min }}(k) \leq \operatorname{SOC}_{i}(k) \leq \operatorname{SOC}_{i}^{\text {max }}(k) \\
& \operatorname{SOC}_{i}^{\text {max }}(1)=\operatorname{SOC}_{i}^{\text {max }}(24)=0.90 * N_{\text {bat }}(i) \text { Batt }_{\text {Size }} \\
& 0 \leq P_{c h_{i}}{ }^{k} \leq 0.6 \cdot N_{\text {bat }}(i) \text { Batt }_{\text {Size }} \\
& 0 \leq P_{\text {dis }_{i}}^{k} \leq 0.6 \cdot N_{\text {bat }}(i) \text { Batt }_{\text {Size }} \\
& P_{\text {dis }_{i}{ }^{k}} \cdot P_{\text {ch }}^{k}=0
\end{aligned}
$$

where, $i$ is the total number of buses in the network .i.e. $\forall i=1,2 \ldots . n b . n b$ is the total number of buses., $\mathrm{k}=$ time $1 . .24 \mathrm{hrs}$.

\section{ALGORITHM USED}

In this paper, the outer and inner layer algorithm with MATLAB and GAMS interfacing is used. In the outer layer, the MATLAB is used for the required load data and load flow algorithm for obtaining the power loss. Whereas the inner layer, GAMS programming is executed for obtaining the battery size, total benefit, market benefit and other variables.

Step 1 Algorithm for outer layer as follows;

(a) Read the system data and ZIP load parameters.

(b) Solve the Monte-Carlo simulation for Wind Turbine and solar power calculation.

Step 2

(a) Run the load flow program for 24-hrs and obtain the base Case total energy loss.

(b) Select the candidate node having the highest energy loss for FC and MT location.

Step 3

(a) Set the initial value of minimum battery size for iteration.

(b) Obatin the total benefit, Market benefit, daily energy loss profile for each battery size.

(c) Obtaine the optimal battery size.

(d) Transfer the all control parameter from MATLAB to GAMS

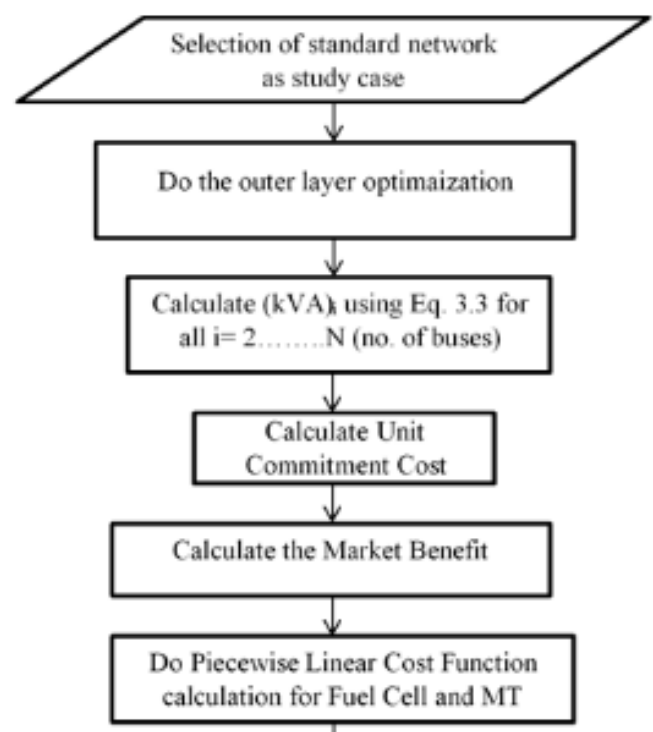

Transfer all the control parameters from MATLAB to GAMS for Inner Layer Optimization

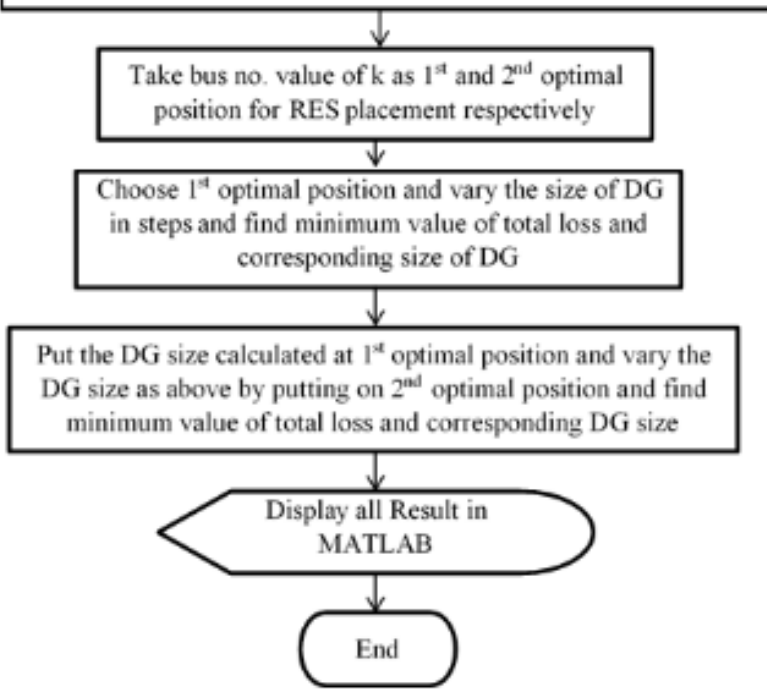

Fig. 5 Two-layer Algorithm used to solve Battery Size in MG

Step 4 Algorithm for inner layer as follows;

(a) Solve the objective function (21) and (22). Solve the constraints equation from (25) to (30) calculate Market Benefit using MINLP solver.

(b) Obtain the size of the battery (3) SOC, charging and discharging of the cell, and solve equation (46) and (50).

(c) Obtain the power output of FC and MT by solving constraints from (31) to (38).

(d) Obtain the cost segment using piecewise linear cost function by solving (10) to (18).

Step 6 Transfer the objective variables form GAMS to MATLAB and get the results.

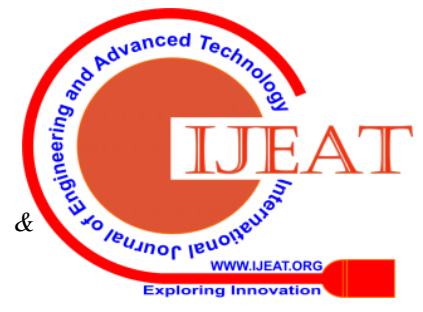


Step 7 Print the results.

The flow chart of the proposed hybrid algorithm is shown in Fig.5.

\section{SYSTEM DATA}

The system data are given in this paper represented as follows;

\section{A. Fuel Cell and Micro-Turbine Data}

The FC and MT power generation data [5] is given in Table I.

Table- I: Generator data for FC and MT [5]

\begin{tabular}{|l|l|l|l|l|l|}
\hline Type & a & b & c & Pmin & Pmax \\
\hline FC & 0.0 & 0.35 & 80 & 100 & 1000 \\
\hline MT & 0.0 & 0.50 & 50 & 100 & 1000 \\
\hline MT & 0.0 & 0.13 & 30 & 100 & 2000 \\
\hline & RU & RD & UT & DT & \\
\hline FC & 30 & 30 & 0 & 0 & \\
\hline MT & 64 & 64 & 0 & 0 & \\
\hline MT & 40 & 40 & 2 & 2 & \\
\hline & CostSD & CostST & R10 & P10 & \\
\hline FC & 57.1 & 57.1 & 500 & 1000 & \\
\hline MT & 50.6 & 50.6 & 500 & 1000 & \\
\hline MT & 42.6 & 42.6 & 1000 & 0 & \\
\hline & SU & U0 & d & r & \\
\hline FC & 80 & 3 & 30 & 0.10 & \\
\hline MT & 140 & 2 & 30 & 0.10 & \\
\hline MT & 110 & 1 & 150 & 0.10 & \\
\hline
\end{tabular}

\section{B. Solar and Wind Turbine cost data}

Table- II: The input data for the energy sources [29], [30] \& [31].

\begin{tabular}{|l|l|l|l|l|l|}
\hline & $\begin{array}{l}\text { Acquisit } \\
\text { ion cost } \\
\mathbf{( \$ )}\end{array}$ & $\begin{array}{l}\text { Operation } \\
\text { and } \\
\text { Maintenance } \\
\text { Cost } \\
\text { (\$/year/kW) }\end{array}$ & $\begin{array}{l}\text { Replacem } \\
\text { ent } \\
\text { Cost } \\
\mathbf{( \$ / L i f e t i ~} \\
\text { me) }\end{array}$ & $\begin{array}{l}\text { Lifes } \\
\text { pan } \\
\text { (year) }\end{array}$ & Rating \\
\hline $\begin{array}{l}\text { PV } \\
\text { module }\end{array}$ & 2400 & 18 & $\begin{array}{l}2.85 \text { @ } \\
\text { 25 year of } \\
\text { life time }\end{array}$ & 25 & $\begin{array}{l}800 \\
(\mathrm{~kW})\end{array}$ \\
\hline $\begin{array}{l}\text { Wind } \\
\text { Turbine } \\
\text { (1MW) }\end{array}$ & 3724.5 & 31 & 3009.5 & 20 & $\begin{array}{l}1000 \\
(\mathrm{~kW})\end{array}$ \\
\hline $\begin{array}{l}\text { Battery } \\
\text { Storage }\end{array}$ & 600 & 20 & $\begin{array}{l}4.64 \text { @ } \\
1.45 \text { year }\end{array}$ & & $\begin{array}{l}100 \\
(\mathrm{kWh})\end{array}$ \\
\hline
\end{tabular}

The input data used in this paper has shown in Table- II. The cost estimation data for the PV-based DG and wind-based DG have been taken from the National Renewable Energy Laboratory (NREL) [29], [30] \& [31]. The data for battery, regulators and investors are taken from the literature [32].

\section{RESULTS AND DISCUSSION}

In this section, the results for the sizing of battery storage is discussed. The multi-objective function has been solved, as explained in section 2. There are two case scenario has been considered as follows;

Case 1: Size of energy storage with wind and solar-based renewable energy sources.

Case 2: Size of energy storage without wind and solar-based renewable energy sources.

\section{A. Case 1}

In this case study, the size of battery energy storage has obtained with WT, PV, FC and MT.

\section{1). Result for the outer layer}

In this section, the result for the outer layer has been discussed. The maximum and minimum size of battery storage obtained is $3000 \mathrm{kWh}$ and $100 \mathrm{kWh}$. The incremental capacity of battery $\left(\Delta\right.$ Batt $\left._{\text {size }}\right)$ taken is $100 \mathrm{kWh}$. Therefore the total 30 number of iteration is taken. In Fig.5, the minimum daily energy loss obtained is $3042.892 \mathrm{kWh}$. Therefore the size of battery storage is $900 \mathrm{kWh}$ at minimum energy loss.

Table-III: Result for battery energy storage size at each size of battery

\begin{tabular}{|c|c|c|c|c|}
\hline $\begin{array}{l}\text { Size of } \\
\text { Battery } \\
\text { (kWh) }\end{array}$ & $\begin{array}{l}\text { Battery } \\
\text { Cost per } \\
\text { day }(\$)\end{array}$ & $\begin{array}{l}\text { Total Benefit } \\
\text { (\$) }\end{array}$ & $\begin{array}{l}\text { Market } \\
\text { Benefit } \\
(\$)\end{array}$ & $\begin{array}{l}\text { Daily Energy } \\
\text { Loss (kWh) }\end{array}$ \\
\hline 100 & 66.97696 & -7606.6 & -7539.63 & 4270.897 \\
\hline 200 & 133.9539 & 2046.153 & 2180.107 & 4054.654 \\
\hline 300 & 200.9309 & 2445.144 & 2646.075 & 3890.979 \\
\hline 400 & 267.9078 & -22.0854 & 245.8224 & 3612.016 \\
\hline 500 & 334.8848 & 5317.934 & 5652.818 & 4346.567 \\
\hline 600 & 401.8617 & -10084.2 & -9682.35 & 889.8202 \\
\hline 700 & 468.8387 & 4028.243 & 4497.081 & 3925.117 \\
\hline 800 & 535.8156 & 1606.186 & 2142.002 & 3969.417 \\
\hline 900 & 602.7926 & 7379.872 & 7982.664 & 3042.892 \\
\hline 1000 & 669.7696 & 7647.786 & 8317.556 & 3965.747 \\
\hline 1100 & 736.7465 & 6358.572 & 7095.319 & 4576.981 \\
\hline 1200 & 803.7235 & 8251.035 & 9054.759 & 3793.969 \\
\hline 1300 & 870.7004 & 5782.677 & 6653.377 & 3203.448 \\
\hline 1400 & 937.6774 & -5348.67 & -4410.99 & 3994.263 \\
\hline 1500 & 1004.654 & -3761.92 & -2757.27 & 3821.006 \\
\hline 1600 & 1071.631 & 8875.188 & 9946.819 & 3565.436 \\
\hline 1700 & 1138.608 & 8850.938 & 9989.546 & 4109 \\
\hline 1800 & 1205.585 & 4921.203 & 6126.788 & 3641.643 \\
\hline 1900 & 1272.562 & -3942.97 & -2670.41 & 3884.087 \\
\hline 2000 & 1339.539 & -7530.15 & -6190.61 & 3631.245 \\
\hline 2100 & 1406.516 & 2060.561 & 3467.077 & 4484.755 \\
\hline 2200 & 1473.493 & 5008.265 & 6481.758 & 3288.303 \\
\hline 2300 & 1540.47 & 678.5209 & 2218.991 & 3903.079 \\
\hline 2400 & 1607.447 & -4494.92 & -2887.47 & 4215.521 \\
\hline 2500 & 1674.424 & 5243.989 & 6918.413 & 3875.806 \\
\hline 2600 & 1741.401 & 6603.386 & 8344.787 & 3649.042 \\
\hline 2700 & 1808.378 & 7046.523 & 8854.901 & 3940.553 \\
\hline 2800 & 1875.355 & 2221.064 & 4096.419 & 3949.684 \\
\hline
\end{tabular}

Blue Eyes Intelligence Engineering \& Sciences Publication 


\begin{tabular}{|l|l|l|l|l|}
\hline 2900 & 1942.332 & 4476.257 & 6418.589 & 4435.717 \\
\hline 3000 & 2009.309 & -5127.37 & -3118.06 & 3745.243 \\
\hline
\end{tabular}

The battery cost per day obtained is $\$ 602.7926$, cost of unit commitment obtained is $\$ 7496.482$, the total benefit obtained is $\$ 7379.872$, the market benefit obtained is $\$ 7982.664$ and fuel cost of FC \& MT obtained is \$ 7261.927. The maximum market benefit obtained is 9989.54(\$) for battery size of 1700 $\mathrm{kWh}$, but the energy loss obtained is $4109 \mathrm{kWh}$. Therefore the best size selection of battery storage is $900 \mathrm{kWh}$.

In the Table-III the cost of market benefit (MB) and minimum energy loss for the size of battery energy storage along with solar and Wind Turbine power is shown.

In this paperwork, the analysis of battery storage of 900 $\mathrm{kWh}$ has been carried out along with the solar and Wind Turbine-based renewable energy sources.

\section{2). Result for inner layer optimization}

In this section, the results for inner layer optimisation is discussed. The battery size obtained in outer layer case is 900 $\mathrm{kWh}$; therefore the inner layer analysis has been done for 900 kWh capacity.

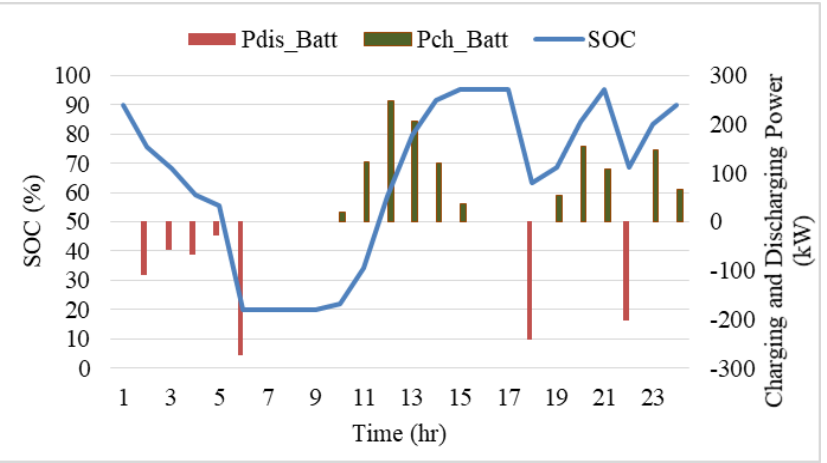

Fig. 6 State of Charge of battery storage with renewable energy sources

In the above Table-III the size of battery energy storage obtained is $900 \mathrm{kWh}$ for minimum energy loss of the distribution network. In Fig.6 red bars are shown to discharging power and green bars for charging power of battery storage, whereas the blue line shows the state of charge for battery in percentage. The negative power indicates the power supplied by battery storage.

The fixed cost of battery storage is $600(\$ / \mathrm{kWh})$ and maintenance cost of BES is $20(\$ / \mathrm{kWh})$. The interest rate is $6.5 \%$ and the life of BES is 3 year taken in this paperwork.

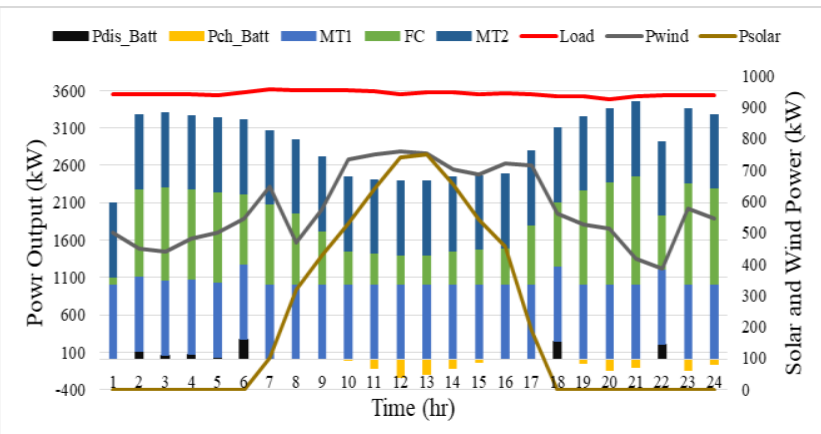

Fig. 7 Power output of fuel cell, Micro-Turbine, battery storage with Wind Turbine and solar based renewable energy sources

The minimum discharge and charging power of the battery set is $0 \mathrm{~kW}$, whereas the maximum discharging and charging power set is $20 \%$ of battery storage size. The initial SOC set is $90 \%$ at time $\mathrm{k}$ of 1 hour. The final SOC for $24^{\text {th }}$ hours is set at $95 \%$ of SOC. Therefore the life of battery storage is better. The Li-ion battery has been selected for this paperwork.

In Fig.7 the power output of fuel cell, micro-turbine, and battery storage with Wind Turbine and solar has been shown. The solar, Wind Turbine-based renewable has been installed at $30^{\text {th }}$ and $15^{\text {th }}$ bus. The micro-turbine (MT1 and MT2), fuel cell are installed at $13^{\text {th }}, 21^{\text {st }}$, and $18^{\text {th }}$ bus, respectively. The obtained size of $900 \mathrm{kWh}$ battery storage has been installed at $19^{\text {th }}$ bus. The maximum power output obtained is $1457.50 \mathrm{~kW}$ of MT, $1000 \mathrm{~kW}$ of FC1 and FC2, $760 \mathrm{~kW}$ of Wind Turbine power and $748.7 \mathrm{~kW}$ of solar energy for 24 hours ZIP load. The required data has been taken from section IV.

\section{B. Case 2}

In this section, the size of battery storage has been obtained without renewable energy sources. The size of battery storage is obtained with MT and FC.

\section{1). Result for the outer layer}

In Table-IV the market benefit-cost and minimum energy loss point has been carried out for the optimal size of battery storage.

Table-IV: Result of outer layer for battery energy storage size at each iteration

\begin{tabular}{|l|l|l|l|l|}
\hline $\begin{array}{l}\text { Size of } \\
\text { Battery } \\
\text { (kWh) }\end{array}$ & $\begin{array}{l}\text { Battery } \\
\text { Cost per } \\
\text { day (\$) }\end{array}$ & $\begin{array}{l}\text { Total } \\
\text { Benefit (\$) }\end{array}$ & $\begin{array}{l}\text { Market } \\
\text { Benefit (\$) }\end{array}$ & $\begin{array}{l}\text { Daily } \\
\text { Energy } \\
\text { Loss (kWh) }\end{array}$ \\
\hline 100 & 66.97696 & 17304.86 & 17371.84 & 4838.601 \\
\hline 200 & 133.9539 & 17163.05 & 17297 & 4593.833 \\
\hline 300 & 200.9309 & 13904.9 & 14105.83 & 4002.295 \\
\hline 400 & 267.9078 & 18054.04 & 18321.94 & 5747.159 \\
\hline 500 & 334.8848 & 2379.403 & 2714.288 & 4836.945 \\
\hline $\mathbf{6 0 0}$ & $\mathbf{4 0 1 . 8 6 1 7}$ & $\mathbf{1 4 5 2 1 . 2 2}$ & $\mathbf{1 4 9 2 3 . 0 8}$ & $\mathbf{3 8 5 4 . 5 5 4}$ \\
\hline 700 & 468.8387 & 14877.28 & 15346.11 & 5116.568 \\
\hline
\end{tabular}

Published By:

Blue Eyes Intelligence Engineering \& Sciences Publication

888 (c) Copyright: All rights reserved. 


\begin{tabular}{|c|c|c|c|c|}
\hline 800 & 535.8156 & 16070.36 & 16606.18 & 5450.305 \\
\hline 900 & 602.7926 & 18912.82 & 19515.61 & 5209.669 \\
\hline 1000 & 669.7696 & -1749.97 & -1080.2 & 3860.991 \\
\hline 1100 & 736.7465 & 11029.84 & 11766.59 & 3904.356 \\
\hline 1200 & 803.7235 & 14286.35 & 15090.07 & 5230.66 \\
\hline 1300 & 870.7004 & 16444.22 & 17314.92 & 5191.115 \\
\hline 1400 & 937.6774 & 11934.66 & 12872.34 & 4221.412 \\
\hline 1500 & 1004.654 & 119.0748 & 1123.729 & 5209.266 \\
\hline 1600 & 1071.631 & 9605.887 & 10677.52 & 4465.198 \\
\hline 1700 & 1138.608 & 12685.79 & 13824.4 & 5158.918 \\
\hline 1800 & 1205.585 & 12773.85 & 13979.44 & 5338.624 \\
\hline 1900 & 1272.562 & 16776.83 & 18049.39 & 4151.34 \\
\hline 2000 & 1339.539 & 15823.58 & 17163.12 & 5586.383 \\
\hline 2100 & 1406.516 & 13689.3 & 15095.81 & 4572.34 \\
\hline 2200 & 1473.493 & 12529.67 & 14003.17 & 5706.083 \\
\hline 2300 & 1540.47 & 14629.05 & 16169.52 & 4590.122 \\
\hline 2400 & 1607.447 & 16362.38 & 17969.82 & 5529.146 \\
\hline 2500 & 1674.424 & 16043.89 & 17718.31 & 5181.696 \\
\hline 2600 & 1741.401 & 14227.51 & 15968.91 & 4815.476 \\
\hline 2700 & 1808.378 & 12014.09 & 13822.46 & 5155.262 \\
\hline 2800 & 1875.355 & 15109.68 & 16985.03 & 4372.484 \\
\hline 2900 & 1942.332 & 15628.77 & 17571.1 & 5812.47 \\
\hline 3000 & 2009.309 & 11936.45 & 13945.75 & 4989.631 \\
\hline
\end{tabular}

The minimum energy loss obtained is $3854.6 \mathrm{kWh}$ for a battery of capacity $600 \mathrm{kWh}$ and market benefit of $14923 \$$ without renewable energy sources. The battery cost per day obtained is \$ 401.8617, cost of unit commitment obtained is \$ 6095.765 , total benefit obtained is $\$ 14521.22$, market benefit obtained is $\$ 14923.08$ and fuel cost of FC \& MT obtained is $\$ 5764.83$. The maximum market benefit obtained is $\$ 18912.82$ for battery storage of $900 \mathrm{kWh}$ and energy loss of $5209.669 \mathrm{kWh}$. Therefore the energy losses have been increased with the size of battery and market benefit also. Consequently, the best size of the battery selected is $600 \mathrm{kWh}$. In this paperwork, the analysis has been carried out for 600 kWh battery along with FC and MT. In Table-IV the market benefit-cost and minimum energy loss-point has been carried out for the optimal size of battery storage. The minimum energy loss obtained is $3854.6 \mathrm{kWh}$ for a battery of capacity $600 \mathrm{kWh}$ and market benefit of $14923 \$$ without renewable energy sources. The maximum market benefit obtained is $\$ 18912.82$ for battery storage of $900 \mathrm{kWh}$ and energy loss of $5209.669 \mathrm{kWh}$. Therefore the energy losses have been increased with the size of battery and market benefit also. Consequently, the best size of the battery selected is $600 \mathrm{kWh}$. In this paperwork, the analysis has been carried out for 600 kWh battery along with FC and MT.

\section{2). Result for inner layer}

In this section the inner layer optimization has been done for analysis of battery obtained size of $600 \mathrm{kWh}$ form outer layer optimization. Therefore the various variables are obtained for $600 \mathrm{kWh}$ battery storage.

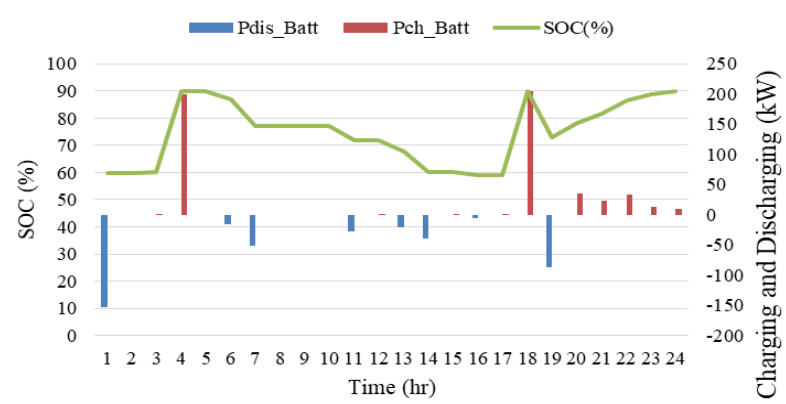

Fig.8 State of Charge of battery storage without renewable energy sources

In the Fig.8 the SOC, charging and discharging power of battery without renewable energy sources is shown. The size of $600 \mathrm{kWh}$ battery storage is carried out for minimum energy loss

The time required for charging and discharging is 2 hours for the battery. The minimum SOC is set at $20 \%$ and maximum at $95 \%$ of battery capacity. The charging and discharging power limit is set at $50 \%$ of the full capacity of battery storage.

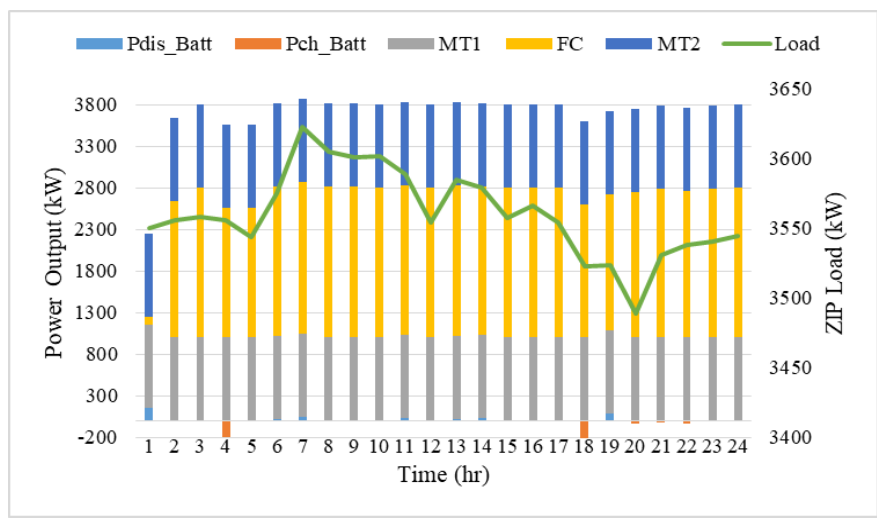

Fig.9 Power output for 24 hrs load variation

In Fig.9 the power output of fuel cell, micro-turbine and battery storage with Wind Turbine and solar has been shown. The two numbers of micro-turbine (MT1 and MT2), fuel cell (FC) are installed at $13^{\text {th }}, 21^{\text {st }}$, and $18^{\text {th }}$ bus, respectively.

The obtained size of $600 \mathrm{kWh}$ battery storage has been installed at $19^{\text {th }}$ bus. The maximum power output obtained is $1457.50 \mathrm{~kW}$ of MT, $1000 \mathrm{~kW}$ of FC1 and FC2, $760 \mathrm{~kW}$ of Wind Turbine power and $748.7 \mathrm{~kW}$ of solar energy for 24 hours ZIP load.
Published By:

Blue Eyes Intelligence Engineering \& Sciences Publication 889 C) Convriaht· All riahts reserved

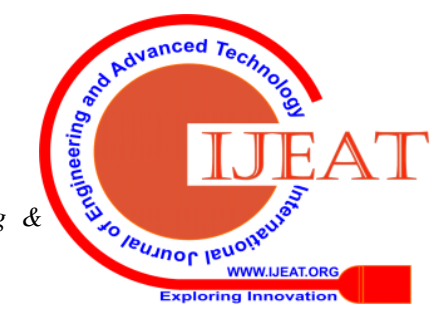




\section{CONCLUSION}

The optimal size of battery energy storage (BES) can be obtained by the method presented in this paper. This method has been tested in IEEE-33 bus test system with considering the network constrained. The time-varying ZIP load model, as explained in section IV, has been considered for observation of the battery impact on the system.

The battery energy storage size obtained for case 1 are 900 $\mathrm{kWh}$ at the lowest energy loss point, and $2700 \mathrm{kWh}$ at the maximum benefit point. The size of BES at the maximum benefit point, the energy loss is maximum as compared with the lowest energy loss point.

Similarly, for Case-2; the size of BES obtained are 600 at lowest energy loss point and $900 \mathrm{kWh}$ at maximum benefit point. Although, the losses has been increased to $26.011 \%$ with consideration of the maximum benefit point for sizing of BES. Therefore the following points are concluded as follows;

1) The battery size obtained is $900 \mathrm{kWh}$ for case 1. In this case the energy loss determine is $3042.89 \mathrm{kWh}$.

2) The battery size obtained is $600 \mathrm{kWh}$ for case 2 . The energy loss determine is $3854.553952 \mathrm{kWh}$.

3) The energy loss is increased in case 2 up to $26.6 \%$ with concerning case 1 . Therefore the use of renewable energy source in MG is beneficial for daily energy saving.

4) The total benefit in case 2 increased up to $48 \%$ with respect to case 1 , because of the maintenance cost of renewable energy source in case 1.

5) The fuel cost of FC and MT in case 2 obtained is $\$ 5674$ and in case 1 obtain is $\$ 7261$. The increment of fuel cost in case 1 is $21.85 \%$.

6) It is concluded that in case 1 at maximum benefit point (at BES size $1700 \mathrm{kWh}$ ) the daily energy loss is increased to $14.65 \%$ with optimal BES of $900 \mathrm{kWh}$ point.

7) The maximum benefit point in case 2 (at BES size of 900 $\mathrm{kWh}$ ) the daily energy loss is increased to $26.011 \%$ with optimal BES of $600 \mathrm{kWh}$.

It is concluded that the optimal size of BES obtained is 900 $\mathrm{kWh}$ in case 1 and $600 \mathrm{kWh}$ in case 2 with considering the minimum daily energy loss.

\section{REFERENCES}

1. K. D. Shinde and P. B. Mane, "Augmenting rooftop solar energy penetration ratio with secondary distribution network using smart inverter for maximum power transfer capacity for subordinate grid-A review," Energy Sources, Part A Recover. Util. Environ. Eff., vol. 41, no. 6, pp. 713-733, 2019, doi: 10.1080/15567036.2018.1520353.

2. J. Zeng, Q. Wang, J. Liu, J. Chen, and H. Chen, "A Potential Game Approach to Distributed Operational Optimization for Microgrid Energy Management with Renewable Energy and Demand Response," IEEE Trans. Ind. Electron., vol. 66, no. 6, pp. 4479-4489, 2019, doi: 10.1109/TIE.2018.2864714.

3. M. Emmanuel, R. Rayudu, and I. Welch, "Grid capacity released analysis and incremental addition computation for distribution system planning," Electr. Power Syst. Res., vol. 152, pp. 105-121, 2017, doi: 10.1016/j.epsr.2017.06.013.

4. D. P. R. P., V. R. V.C., and G. M. T., "Ant Lion optimization algorithm for optimal sizing of renewable energy resources for loss reduction in distribution systems," J. Electr. Syst. Inf. Technol., vol. 5, no. 3, pp. 663-680, 2018, doi: 10.1016/j.jesit.2017.06.001.

5. S. X. Chen, H. B. Gooi, and M. Q. Wang, "Sizing of energy storage for microgrids," IEEE Trans. Smart Grid, vol. 3, no. 1, pp. 142-151, 2012, doi: 10.1109/TSG.2011.2160745.

6. B. Bahmani-Firouzi and R. Azizipanah-Abarghooee, "Optimal sizing of battery energy storage for micro-grid operation management using a new improved bat algorithm," Int. J. Electr. Power Energy Syst., vol. 56, pp. 42-54, 2014, doi: 10.1016/j.ijepes.2013.10.019.

7. W. Su, J. Wang, and J. Roh, "Stochastic energy scheduling in microgrids with intermittent renewable energy resources," IEEE Trans. Smart Grid, vol. 5, no. 4, pp. 1876-1883, 2014, doi: 10.1109/TSG.2013.2280645.

8. A. A. Moghaddam, A. Seifi, T. Niknam, and M. R. Alizadeh Pahlavani, "Multi-objective operation management of a renewable MG (micro-grid) with back-up micro-turbine/fuel cell/battery hybrid power source," Energy, vol. 36, no. 11, pp. 6490-6507, 2011, doi: 10.1016/j.energy.2011.09.017.

9. M. P. Bonkile and V. Ramadesigan, "Power management control strategy using physics-based battery models in standalone PV-battery hybrid systems," J. Energy Storage, vol. 23, no. December 2018, pp. 258-268, 2019, doi: 10.1016/j.est.2019.03.016.

10. F. Fan, W. Huang, N. Tai, X. Zheng, Y. Hu, and Z. Ma, "A conditional depreciation balancing strategy for the equitable operation of extended hybrid energy storage systems," Appl. Energy, vol. 228, no. April, pp. 1937-1952, 2018, doi: 10.1016/j.apenergy.2018.07.049.

11. W. Wang, C. Mao, J. Lu, and D. Wang, "An energy storage system sizing method for wind power integration," Energies, vol. 6, no. 7, pp. 3392-3404, 2013, doi: 10.3390/en6073392.

12. R. Levy, A. Brodsky, and J. Luo, "Decision guidance framework to support operations and analysis of a hybrid renewable energy system," $J$. Manag. Anal., vol. 3, no. 4, pp. 285-304, 2016, doi: 10.1080/23270012.2016.1229140.

13. V. V. S. N. Murty and A. Kumar, "Multi-objective energy management in microgrids with hybrid energy sources and battery energy storage systems," Prot. Control Mod. Power Syst., vol. 5, no. 1, pp. 1-20, 2020, doi: 10.1186/s41601-019-0147-z.

14. X. Wang, M. Yue, E. Muljadi, and W. Gao, "Probabilistic approach for power capacity specification of wind energy storage systems," IEEE Trans. Ind. Appl., vol. 50, no. 2, pp. 1215-1224, 2014, doi: 10.1109/TIA.2013.2272753.

15. D. Fioriti and D. Poli, "A novel stochastic method to dispatch microgrids using Monte Carlo scenarios," Electr. Power Syst. Res., vol. 175, no. December 2018, p. 105896, 2019, doi: 10.1016/j.epsr.2019.105896.

16. Y. M. Atwa, E. F. El-Saadany, M. M. A. Salama, R. Seethapathy, M. Assam, and S. Conti, "Adequacy evaluation of distribution system including wind/solar DG during different modes of operation," IEEE Trans. Power Syst., vol. 26, no. 4, pp. 1945-1952, 2011, doi: 10.1109/TPWRS.2011.2112783.

17. G. Ma et al., "A Bi-Level Capacity Optimization of an Isolated Microgrid with Load Demand Management Considering Load and Renewable Generation Uncertainties," IEEE Access, vol. 7, pp. 8307483087, 2019, doi: 10.1109/ACCESS.2019.2924288.

18. N. D. Hatziargyriou, A. G. Tsikalakis, N. D. Hatziargyriou, and S. Member, "Centralized Control for Optimizing Microgrids Operation Central Controller Strategy to Optimize Microgrids Operation," 2011 IEEE Power Energy Soc. Gen. Meet., no. November 2015, pp. 1-8, 2011, doi: 10.1109/PES.2011.6039737.

19. C. Abbey and G. Joós, "A stochastic optimization approach to rating of energy storage systems in wind-diesel isolated grids," IEEE Trans. Power Syst., vol. 24, no. 1, pp. 418-426, 2009, doi: 10.1109/TPWRS.2008.2004840.

20. M. Marzband, M. Ghadimi, A. Sumper, and J. L. Domínguez-García, "Experimental validation of a real-time energy management system using multi-period gravitational search algorithm for microgrids in islanded mode," Appl. Energy, vol. 128, pp. 164-174, 2014, doi: 10.1016/j.apenergy.2014.04.056.

21. M. Asensio, G. Muñoz-Delgado, and J. Contreras, "Bi-level approach to distribution network and renewable energy expansion planning considering demand response," IEEE Trans. Power Syst., vol. 32, no. 6, pp. 4298-4309, 2017, doi: 10.1109/TPWRS.2017.2672798.

22. P. Fortenbacher, J. L. Mathieu, and G. Andersson, "Modeling and Optimal Operation of Distributed Battery Storage in Low Voltage Grids," IEEE Trans. Power Syst., vol. 32, no. 6, pp. 4340-4350, 2017, doi: 10.1109/TPWRS.2017.2682339.

Published By:

Blue Eyes Intelligence Engineering Sciences Publication 
23. G. M. Kaci, A. Mahrane, K. Ghedamsi, and M. Chikh, "Influence of Battery Storage on Self - Consumption of Residential Photovoltaic Systems in a Mediterranean Climate," no. 3, pp. 412-416, 2019.

24. M. V. Ramesh, P. Sowjanya, and V. S. G. Lakshmi, "PV system powered BLDC motor with energy storage," Int. J. Eng. Adv. Technol., vol. 8, no. 6 Special Issue 3, pp. 881-883, 2019, doi: 10.35940/ijeat.F1152.0986S319.

25. K. Aseem and S. Selva Kumar, "A novel controller for isolated solar photovoltaic system with super conducting magnetic energy storage and fault ride through capability," Int. J. Eng. Adv. Technol., vol. 9, no. 1, pp. 4344-4352, 2019, doi: 10.35940/ijeat.A1872.109119.

26. C. L. T. Borges and D. M. Falcão, "Optimal distributed generation allocation for reliability, losses, and voltage improvement," Int. J. Electr. Power Energy Syst., vol. 28, no. 6, pp. 413-420, 2006, doi: 10.1016/j.ijepes.2006.02.003.

27. A. Soroudi, Alireza Soroudi Power System Optimization Modeling in GAMS. 2019.

28. Y. Zhang, Y. Xu, H. Yang, and Z. Y. Dong, "Voltage regulationoriented co-planning of distributed generation and battery storage in active distribution networks," Int. J. Electr. Power Energy Syst., vol. 105, no. May 2018, pp. 79-88, 2019, doi: 10.1016/j.ijepes.2018.07.036.

29. L. A. Bird, K. S. Cory, and B. G. Swezey, "Renewable Energy PriceStability Benefits in Utility Green Power Programs," Nrel, no. August, 2008.

30. IRENA International Renewable Energy Agency, Renewable Power Generation Costs in 2017. 2018.

31. N. R. E. Laboratory, "Distributed Generation Renewable Energy Estimate of Costs Database," 2013, [Online]. Available: http://www.nrel.gov/analysis/tech lcoe re cost est.html.

32. M. H. Mostafa, S. H. E. A. Aleem, S. G. Ali, A. Y. Abdelaziz, P. F. Ribeiro, and Z. M. Ali, "Robust energy management and economic analysis of microgrids considering different battery characteristics," IEEE Access, vol. 8, pp. 54751-54775, 2020, doi: 10.1109/ACCESS.2020.2981697.

\section{AUTHORS PROFILE}

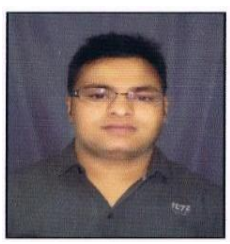

Bharat Singh: Received his B.Tech degree form GBPEC Pauri, UK in 2012 and M.Tech degree from NIT Hamirpur, India in 2016. He is currently pursuing Ph.D. from Electrical Engineering department in NIT Kurukshetra from 2018. His area of interest includes the dispatch strategy of Micro-Grid. He is life time member of Indian Society for Technical Education (ISTE) and Member of (IEEE).

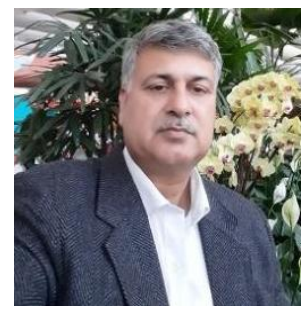

Dr. Ashwani Kumar, SM(IEEE), FIE (I), LMISTE, Professor in Department of Electrical Engineering National Institute of Technology, Kurukshetra, Haryana, India 136119. He is the senior IEEE member and has 27 year of teaching experieance. His area of interest includes Power Systems Restructuring, Distributed Generation and Renewable Energy Systems, Renewable energy integration issues in deregulated power systems, Harmonics mitigation and pricing issues, FACTS applications to Power Systems, Demand Side Management, energy management.
Published By:

Blue Eyes Intelligence Engineering Sciences Publication

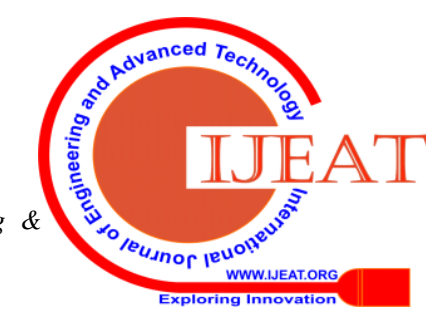

